\title{
Belief, Preference and Constraint Factors Influencing Malaysian Accounting Students' Intention to Pursue Professional Qualification
}

\author{
Hani Hamizah Nor Hashim, Erlane K Ghani* \\ Faculty of Accountancy, Universiti Teknologi MARA, Malaysia
}

Received December 3, 2019; Revised January 21, 2020; Accepted February 7, 2020

Copyright $\odot 2020$ by authors, all rights reserved. Authors agree that this article remains permanently open access under the terms of the Creative Commons Attribution License 4.0 International License

\begin{abstract}
This study investigates the factors influencing accounting students' intention to pursue a professional qualification upon graduation. By employing the Belief, Preference and Constraint (BPC) Model from the Behavioral Decision Theory (BDT), the study utilized the quantitative method by sampling 245 final year accounting students from Malaysian public universities. This study shows that students' preference to hold a professional membership, as well as their job prospect beliefs, social beliefs and capability beliefs are all positively and significantly associated with their intention to pursue a professional qualification. Findings further indicate that the constraints faced by the students have a negative but insignificant impact on students' intentions. This study thus contributes to the accounting education literature in Malaysia by providing evidence with regards to the major determinants of the accounting students' intentions to pursue a professional qualification post-university, hence providing insight to students' career-decision-making process. Extant literature has predominantly focused on the context of more developed countries thus this study provides valuable insights from the perspective of a developing country in Southeast Asia. Further, this study utilizes the BDT which differs from most prior career decision making studies.
\end{abstract}

Keywords Belief, Preference, Constraint, Accounting Students, Professional Qualification

\section{Introduction}

The scope of work for professional accountants has grown so much over the years that the participation of these professionals can be seen in nearly every field and stage of a business, from carrying out typical audit work and tax planning to offering professional advice on capital budgeting, financial structure and investment decisions. Clearly, the skills and expertise offered by professional accountants are exceptionally important in maintaining a healthy accounting system and business environment, and by extension, a stable and vibrant economy. It is thus unsurprising that the global demand for professional accountants has continuously been on the rise, as the profession is vital in providing invaluable support to businesses in multiple areas. The ever-changing accounting regulations and economic landscape, in addition to the increasing complexity of todays' businesses due to rapid globalization, has only added to the heightened need for professional accountants (ACCA Global, 2016; Monga, 2017). However, unbeknownst to many, this increase in demand for professional accountants is actually not matched with a comparable increase in supply. In fact, many countries have reported a similar problem, albeit the shortage may be fueled by various reasons in the different parts of the world.

A recent study carried out by Korn Ferry Consulting estimated that a talent shortage crisis is expected to be most severe in the financial and business services sector, with a potential deficit of 10.7 million workers globally by 2030 and as consequence, a possible annual loss of revenues amounting to $\$ 1.3$ trillion (Kurschner, 2018). The USA 2016 Bureau of Labor Statistics (BLS) Occupational Handbook reported that employment for auditors and accountants are expected to grow at an $11 \%$ rate from 2014 to 2024, representing an additional 142,000 jobs (AICPA, 2017). As highlighted by the American Institute of CPAs (AICPA) president and CEO, Barry Melancon, CPAs remain uniquely positioned to take advantage of the changing employment trends, thus reflecting the bright job prospects for those who have earned their CPA license. Yet, the economy continues to face an accounting and audit talent shortage (Whitehouse, 2015). 
Malaysia, a developing country in the Southeast Asia region, is also not excluded from this shortage issue of professional accountants. Accountants and financial analysts are reportedly included as part of the 58 skilled, sought-after and strategic occupations listed in the Critical Occupation List (COL) 2017/2018 Report by Talentcorp Malaysia and the Institute of Labour Market Information and Analysis (ILMIA). According to the Economic Transformation Program (ETP) roadmap launched in 2010, Malaysia views the accounting sector not only as a supporting foundation to the nation's economic viability, but also a business opportunity whereby the country may export accounting services to outside of Malaysia. To do so, however, it is critical to enhance the quality of the country's accountants, hence the urgency for accountants to hold a recognized professional qualification (Oh, 2014). Furthermore, in its current mission to achieve a high-income nation status between 2020-2024, Malaysia's need for qualified accountants is now as crucial as ever, whereby the country aims to have at least 60,000 professional accountants by the year 2020 (ACCA Global, 2018; "Malaysia needs 60000 accountants", 2015). Although the number of registered MIA members have been steadily increasing at an average of 1000 members per year, statistics from MIA's Membership Department show that, as of 31st May 2019, the total number of accountants registered under MIA is only at 35,629 members, which is still a far cry from the required number of professionals in the accounting field. Considering the trend of growth, Malaysia may need more time to achieve the targeted 60,000 mark, because it is unlikely that Malaysia will be able to fill that gap by 2020 (Lee, 2018) as it stands now.

This study aims to examine the factors influencing accounting students' intention to pursue a professional qualification upon graduation. The findings of this study will contribute to the accounting education literature in Malaysia, differing from prior literature which predominantly focuses on the context of Western and more developed countries. The next section Section 2 provides the literature review. This is followed by Section 3 that explains the research design and Section 4 presents the results and discussion. The last section Section 5 concludes this paper.

\section{Literature Review}

\subsection{The Accounting Career}

The accounting profession in Malaysia is one that is highly regulated, whereby the national accountancy body, namely the Malaysian Institute of Accountants (MIA), was established under the Accountants Act 1967. The Act provides that to be an accountant in Malaysia, one may either register with MIA upon graduating with an accounting degree from local universities listed in the First
Schedule of the Act plus three years of relevant working experience, or become a member of a recognized professional accounting body such as the Association of Chartered Certified Accountants (ACCA), Malaysian Institute of Certified Public Accountants (MICPA), Institute of Chartered Accountants in England and Wales (ICAEW), CPA Australia or the Chartered Institute of Management Accountants (CIMA).

The scope of an accounting profession is relatively wide; it is no longer limited to the number crunching role that many traditionally assume it to be. The application of accounting principles and skill sets can lead to an array of accounting career pathways which includes the likes of being a public accountant, management accountant, auditor, tax accountant, cost accountant, forensic accountant, financial analysts or risk manager, among many others. Ghani, Said, Nasir, and Jusoff (2008) and Yusoff, Omar, Awang, Yusoff and Jusoff (2011) found that Malaysian accounting students appear to prefer becoming public accountants as compared to other accounting careers, although this may be due to the students' lack of awareness of other accounting pathways. Nevertheless, an accountant may also choose to specialize according to industry or specific roles within an organization. Hence, the type of education, professional certification or level of training that they will undergo will highly depend on the nature of the job that they choose.

As such, the pathway towards an accounting career can be attributed to numerous factors. Yusoff et al. (2011) found that students' exam grades are not determinants of their knowledge of a professional accounting career. Other studies examined the impact of cultural differences, as determined by race, on the accounting students' perception towards the accounting career (Ghani \& Said, 2009). Extant literature that has examined the factors in determining the decision making process in one's pursuance of a professional accounting career has primarily focused on the western context while those carried out in the local context is still relatively limited (Jaffar, Ismail \& Zahid, 2015). Therefore, it is timely for a study that may further contribute to the accounting education literature in Malaysia, specifically those focusing on the determinants of students' decision to practice as professional accountants, given that the number of professional accountants are still very lacking in the country.

\subsection{Factors Affecting Students' Intention to Pursue an Accounting Career}

\subsubsection{Job Prospect Belief}

Good job prospects essentially refer to the benefits that is expected to be received upon pursuing a particular job, such as the benefit of having marketability, high salary, good job security and job stability, as well as the opportunity for career advancements. Some studies have 
collectively termed the motivation to achieve these positive job prospects as 'extrinsic interests' (Felton, Buhr \& Northey, 1994; Ahmed, Alam \& Alam, 1997; Jackling \& Calero, 2006; Ahmad et al., 2015) as they are essentially financial remunerations and market-related factors that are extrinsic to the nature of the job in question. Belief or perception about the expected financial remuneration and market-related incentives has been extensively studied in career-related literature to determine its influence on individual's career decisions. The perception towards salary, in particular, has nearly always been deemed an important determinant of an individual's career choice. Many older literatures have found salary to be a significant attribute that individual take into account when deciding career pathway (e.g. Trump and Hendrickson, 1970; Carpenter \& Strawser, 1970). However, the importance of salary as major determinant may have shifted over time as demonstrated by the contradicting results of more recent studies (Ahmad et al., 2015; Law, 2010)

Felton et al. (1994) carried out an extensive study in Canada involving 897 business students from eight Canadian universities. The study looked at how students perceive job market considerations, good initial and long-term financial remuneration, along with several other factors, and examined the correlation with the students' subsequent intention to pursue a Canadian Chartered Accountant. A similar study was carried out by Ahmed et al. (1997) in New Zealand, whereby the study surveyed 295 students from five universities, examining the difference between group of accounting students that intend to do CA and group that does not, in their attitude towards the importance of financial and job-market factors as well as intrinsic factors and other factors. Felton et al. (1995), Allen (2004) and Tan and Laswad (2006) are among the many studies that later utilized the TRA and TPB, whereby the 'attitude' component of the theories examined students' underlying job prospect beliefs which could influence their attitude and subsequent intention to pursue an accounting career.

Many local studies have also extensively examined job-related rewards as an expected significant factor that influence accounting students' career choice. A qualitative exploratory study by Muhamad, Salleh and Nordin (2016) in Malaysia show that students' perception on career opportunity and salary as among the influencing factors cited to have effect on students' decision to pursue the qualification. Mustapha and Hassan (2012), on the other hand, specifically investigated job-related rewards only, whereby their study examined students' perception on salary, opportunities for advancement, prestige or status of holding qualification and job security and stability. The specific focus on students' perception on job prospects allow the identification of the type of job-related reward that is perceived to be most important to the accounting graduates. A study by Aziz, Ibrahim, Sidik and Tajuddin (2017) focused on Bumiputra accounting students, whereby the study examined the Bumiputra students' perception towards the job prospects of the profession and subsequent intention to pursue a professional qualification. Results were compared with the non-Bumiputra student counterparts.

In summary, according to these literature, if the student places high importance to job-related rewards (e.g. high salary, good job security and stability, career advancements opportunities, etc.) when choosing a career, and/or if they believe that pursuing an accounting professional qualification will provide such job prospects, it is generally expected that the accounting student would have greater intention to pursue the qualification upon graduation. Nevertheless, based on the vast literature that supports the notion that positive job beliefs is a key motivation for pursuing a professional qualification, the hypothesis proposed is as follows:

H1: Positive job prospects beliefs in holding a professional qualification has a significant positive relationship with students' intention to pursue the qualification

\subsubsection{Social Belief}

Social belief refers to one's beliefs that are the products of his social interactions. Behavioral psychologist asserted that one's behavior is the product of his social interactions, hence suggesting that one's social attributes can be used to analyze and explain behavior (Bandura, 1986), such as individual's career decisions. In fact, the social interaction factor has been included as the building block of a number of behavior-related theoretical models such as the TRA and TPB (Ajzen \& Fishbein, 1980; Ajzen, 1991). Ajzen (1991) termed one's perception of his social pressures to undertake a particular action as subjective norms. A similar idea is put forward by Jackling and Keneley (2009) who defined that normative beliefs are beliefs that are developed due to the influence of views and opinions of other people. To date, a number of studies have illustrated that the views of social figures deemed important to one's life, such as parents, peers and teachers, which are significant factors that influence students' social beliefs and hence their subsequent career intention. Using TPB, Tan and Laswad (2006) and Wen et al. (2015) examined New Zealand and Chinese students' normative beliefs of the views of important referents towards their accounting major as well as the degree of importance they place on the referents' views. Similarly, by utilizing the TRA, studies such as Djatej, Chen, Eriksen and Zhou (2015) and Law (2010) conducted studies in the US and Hong Kong, respectively, to examine how social influences from important figures affect students' intention to major in accounting.

According to Bauder (2006), South Asians highly value social status, thus are more likely to choose a profession that provide with high social status or prestige. Auyeung and Sands (1997) examined 12 career-choice factors, 
which included the examination of the effects of parental influence, teachers' influence, peers' influence and association with others in the field. The study collected responses from tertiary students from Australia, Hong Kong and Taiwan universities. Findings show that the influence of important social figures was significantly greater amongst the Asian students (i.e. Hong Kong and Taiwan) compared to students from Australia. The results highlight how different cultures and social environment can affect how individuals weigh the opinions of people around them and thus, lead them to act accordingly. This impact of cultural differences is similarly noted by Law and Yuen (2012), whose findings also show that influence of social norms is more significant among Asian students rather than Western students. This is unsurprising considering how the Asian culture, in general, values familial opinions more than the Western culture.

Several studies additionally compared the accounting students and non-accounting student's perception of social prestige attributed to the accounting profession (Felton et al., 1994; Tan \& Laswad, 2006; Sugahara \& Boland, 2006). Sugahara and Boland (2009) extended their prior study to also examine the impact of social influence, terming it as 'person's influence', on accounting and non-accounting students' intention to pursue CPA. Other studies in Malaysia such as that by Mustapha and Hassan (2012), Ahmad et al. (2015) and Aziz et al. (2017) have also studied the impact of accounting student's social beliefs of having professional qualifications. Only Ahmad et al. (2015) found significant results for subjective norms as one of the key determinant of students' intention is to become accountants, while neither Mustapha and Hassan (2012) nor Aziz et al. (2017) found any evidence to support the notion that holding a professional qualification is important by virtue of the prestige and status of the qualification. Therefore, the following hypothesis is developed:

H2: Positive social beliefs of holding a professional qualification has a significant positive relationship with students' intention to pursue the qualification

\subsubsection{Capability Belief}

Capability belief, or also frequently referred to as self-efficacy, is the belief in one's own capability to successfully carry out certain behaviors or activities, which will allow the individual to achieve his desired goal (Bandura, 1986). It revolves around one's own perception, thus it is dissimilar to more objective and actual measurements of abilities (Schoenfeld, Segal \& Borgia, 2015). A similar notion of belief in capability is also discussed under the perceived behavioral control component of the TPB by Ajzen (1991), whereby it asserts that one's perception of the degree of easiness or difficulty faced to successfully perform a particular behavior will be a predictor of his intention and ultimate decision to perform that behavior. As noted by Bandura (1986), one who has greater beliefs in his capability to achieve desired goal or performance is more likely to pursue the activity. Likewise, other studies have found that high self-efficacy beliefs are greatly associated with career interests (Brown, Lent, Telander, \& Tramayne, 2011; Lent et al., 1994).

There is a number of literature that have examined underlying capability belief and its link to individual's intention to pursue an accounting major or professional accounting career. Under the BPC-BDT model, Owusu, Obeng, Ofori, Ossei Kwakye \& Bekoe (2018) studied Ghanaian business students' belief in their own capabilities, and whether it directly influences them to pursue a professional accounting qualification or not. This included whether they believe they had the confidence, relevant knowledge, experience or mental fortitude to allow success in attaining a CPA certification. Schoenfeld et al. (2017) and Hayes and Credle (2008) applied the SCCT model to examine the relationship between students' self-efficacy or self-confidence in becoming a CPA and the individual's subsequent goal of becoming one, and whether they believed they would be able to achieve the expected outcome of a CPA career or not. Under the perceived control construct of TPB, Tan and Laswad (2006) examined students' perceived capability in mathematics and performance in the accounting course, while Wen et al. (2015) measured Chinese accounting students' perception of difficulty in passing the CPA exams with their intention to pursue the CPA. According to the relatively mixed findings of Albeit this study would propose the following hypothesis:

H3: Belief in capability to achieve a professional qualification has a significant positive relationship with students' intention to pursue the qualification

\subsubsection{Preference}

Preference refers to the individual's inherent predisposition which in turn influences the decisions making (Owusu et al., 2015). Under the preference component of the BPC-BDT model, Owusu et al. (2018) examined students' preference for a professional qualification on the basis that it complements the individual's self-goal, aiming to work in audit firm, or for providing the challenge of pursuing the membership. Acting in accordance to one's own preference is expected to give satisfaction to the individual. A similar notion is commonly referred to as intrinsic interest, whereby it is defined as the satisfaction derived from a job or status, which provides benefits such as the opportunity to be independent and creative, providing a dynamic and intellectually challenging environment, or by allowing the desired autonomy to the individual (Amabile, Hill, Hennessey, \& Tighe, 1994). Hence, pursuing the activity is perceived to create pleasure and enjoyment within the individual, hence motivate him to carry out the behavior. Ahmad et al. (2015) further highlighted that intrinsic interest differs from extrinsic interest which primarily relates to financial and market-based rewards which are 
attached extrinsically to the nature of the job itself.

Many prior literature generally reported that accounting students place a much lower value to intrinsic interest (e.g. Gul, Andrew, Leong, \& Ismail, 1989; Ahmed et al, 1997). This largely reflects how earlier students may not attach much importance to personal preference or intrinsic factors, but instead viewed other forms of incentives, such as financial remuneration and market-related benefits, as more determining factors in their choice to pursue the career. Nevertheless, later research tend to contradict these results as students were reported that they prefer jobs that they find interesting or provides with independent work environment, whereby such intrinsic factors are significant motivating factors for them when choosing an accounting major or career (Jackling \& Calero, 2006; Sugahara \& Boland, 2009; Law, 2010; Djatej et al., 2015). Jackling and Keneley (2009) notes that students who are engaged in interest-oriented learning are more competent with recognizing and solving complicated problems as compared to students who are solely motivated by the financial and career-related rewards. Wen et al (2015) thus additionally commented on the importance of creating genuine interest in the profession if the accounting field aims to attract more students.

Accounting literature also show that there could be differences in preference towards the accounting career between different student groups. For example, study by Tan and Laswad (2006) found that accounting majors and non-accounting majors have different career preferences, as indicated by their perception towards the accounting profession. Sugahara, Boland and Cilloni (2008) carried out a comparison study to examine factors that influence Chinese and Australian students' choice to major in accounting. Results indicate that the Chinese students are much less concerned with intrinsic factors than the Australian students, reflecting that preference for accounting major could differ due to differences in cultural influences. Overall, the literature findings lead to the following hypothesis:

H4: Preference to hold a professional qualification has a significant positive relationship with students' intention to pursue the qualification

\subsubsection{Constraints}

Constraints refer to the external factors that hinders one from acting out a particular activity (Owusu et al., 2018). As noted by Ahmad et al (2015), there is relatively limited literature that directly links constraints or anticipated conflicts to students' intention whether to pursue a professional qualification or not. Yet, numerous literatures in career development have consistently shown that constraints in the form of anticipated career conflicts could greatly influence one's career intention and subsequent career pathway (e.g. Baker, 2010). Constraints to pursuing the professional qualification can arise from a variety of reasons. For example, the pursuit of a professional accounting career can interfere with family responsibilities, whereby Weer, Greenhaus and Cokakoglu (2006) had previously defined anticipated work-family conflict as the students' perceptions of the potential for conflict between work and family roles after embarking on careers. Noting that family considerations can greatly affect one's career intentions, Ahmad et al. (2015) examined accounting students' perception of the career with regards to the degree the work demands of the profession would conflict with social and family responsibilities, as well as hindering the individual from pursuing other interests and hobbies. Pasewark and Viator (2006) highlighted in their study that high turnovers in accounting firms are also attributed to the work-family conflicts faced on the job.

Felton et al. (1994) and Ahmed et al. (1997) used the benefit-cost ratio to determine students' attitude towards the accounting profession, whereby the perceived costs that were considered included degree of difficulty to qualify for CA career, low initial earnings, having to deal with the then negative and dull image of accountants and the belief that there is minimal relaxation especially in the earlier years of a CA career. Qualitative research by Nasir, Ghani and Said (2009) explored the reasons accounting graduates in Malaysia do not become professional accountants. Primary reason cited were due to their belief that it is too difficult to fill in membership form, the high cost of maintaining the membership, their belief that there is limited added benefits of having a professional qualification as well as due to graduates' own lack of ambition.

In terms of time constraints, many studies have highlighted how a significant amount of time has to be dedicated in order to obtain a professional qualification, hence being a major setback and discouraging factor for students to continue pursuing an accounting profession (Albrecht \& Sack, 2000). Other studies such as that by Aziz et al. (2017) and Owusu et al. (2018) examined the impact of financial costs of associated with pursuing the professional exams. This is primarily because taking up exams and maintaining the membership can be very costly, and as such, can also act as a major hindrance in pursuing the qualification. Therefore, the hypothesis proposed is as follows:

H5: Constraints in attaining the professional qualification has a significant negative relationship with students' intention to pursue the qualification

Figure 1 depicts the proposed research framework of this study. The research framework is built based on the BPC model from the BDT, which will thus examine whether belief, preference and constraint factors hold any influence towards the expected behavior or not. As shown in Figure 1 , the accounting student' job prospect beliefs, social beliefs, capability beliefs, preferences and constraints are the independent variables that potentially influence the dependent variable, namely the students' intention to pursue a professional qualification. 


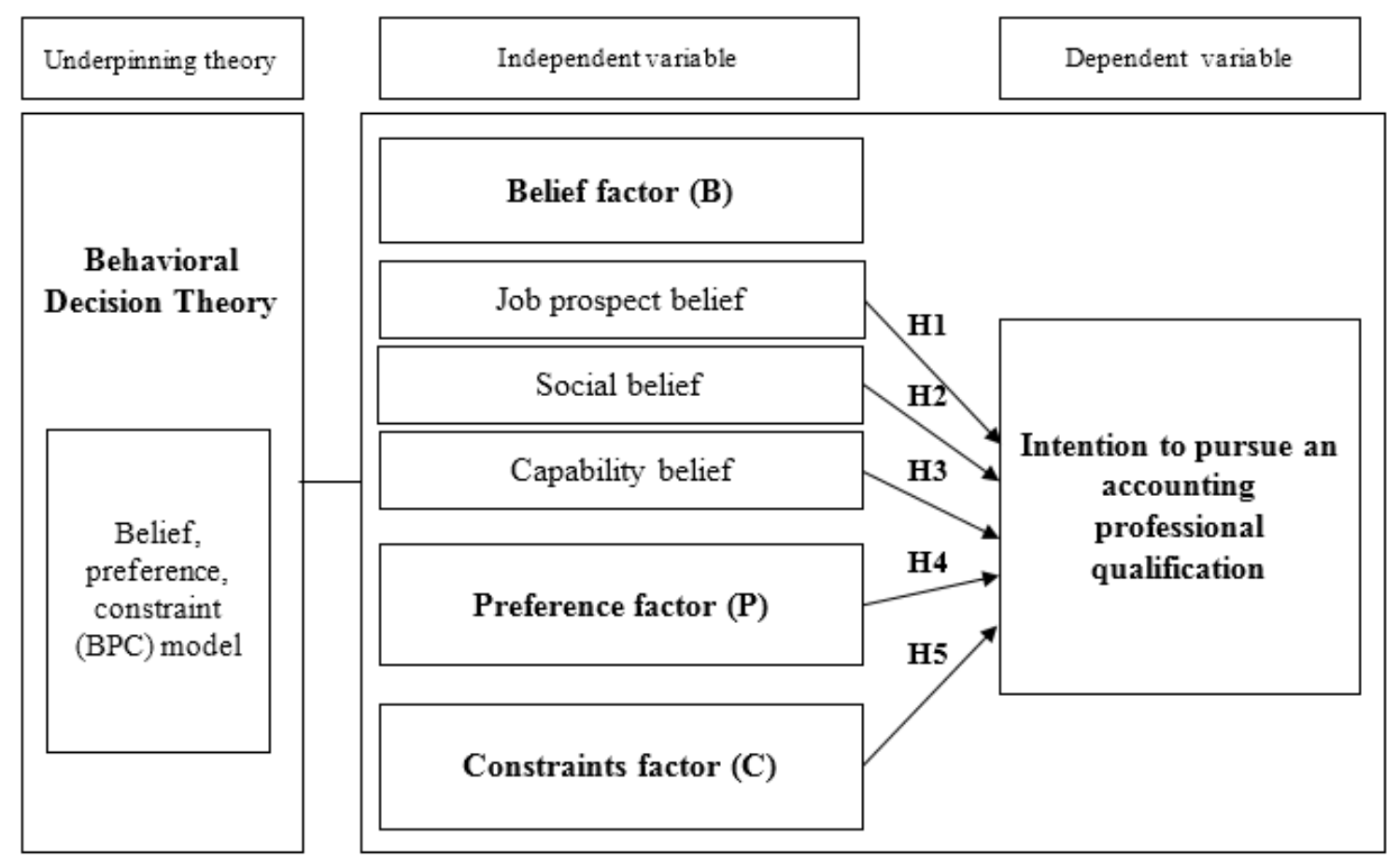

Figure 1. Research Framework

\section{Research Design}

\subsection{Sample Selection}

The target population is accounting students enrolled in undergraduate Bachelor of Accountancy programs in Malaysian public universities. The sample respondents were narrowed down to final year accounting students of their respective universities. Final year accounting students were selected because they are more likely aware and clear of their career intentions following their graduation, thus likely offer better insights into the factors associated with their intention to pursue the professional qualification (Mustapha \& Hassan, 2012).

\subsection{Research Instrument}

Table 1. Summary of Sections in Research Questionnaire

\begin{tabular}{|c|l|}
\hline Section & \multicolumn{1}{|c|}{ Description } \\
\hline $\begin{array}{c}\text { Section } \\
\text { A }\end{array}$ & $\begin{array}{l}\text { General information that covers respondents' } \\
\text { demographic profile such as age, gender, year of study, } \\
\text { institution, and grade point average. }\end{array}$ \\
\hline $\begin{array}{c}\text { Section } \\
\text { B }\end{array}$ & $\begin{array}{l}\text { Measure the students intention to pursue a } \\
\text { professional qualification upon graduation. }\end{array}$ \\
\hline $\begin{array}{c}\text { Section } \\
\text { C }\end{array}$ & $\begin{array}{l}\text { Measure the impact of students' beliefs regarding the } \\
\text { professional qualification towards their intention to the } \\
\text { qualification }\end{array}$ \\
\hline $\begin{array}{c}\text { Section } \\
\text { D }\end{array}$ & $\begin{array}{l}\text { Measure the impact of students' preference for a } \\
\text { professional qualification towards their intention to } \\
\text { pursue the qualification }\end{array}$ \\
\hline $\begin{array}{c}\text { Section } \\
\mathrm{E}\end{array}$ & $\begin{array}{l}\text { Measure the impact of constraints faced by students } \\
\text { towards their intention to pursue a professional } \\
\text { qualification }\end{array}$ \\
\hline
\end{tabular}

Questionnaire survey was used as the research instrument for this study. The questionnaire was developed by adapting the research instruments administered by similar studies conducted by Ahmad et al. (2015) and Owusu et al. (2018). The questionnaire for this study consisted of five (5) sections, namely Section A, B, C, D and E. A brief overview of the data collected in each section of the questionnaire is summarized in Table 1.

\subsection{Data Collection}

Data was collected via the administration of an online questionnaire to target respondents, namely final year accounting students in Malaysian public universities. The data collection process was carried out over a period of time, starting from the time the online questionnaire was firstly distributed to the academic staff of the public university. A second email was sent a week later to follow up on the academic staff whom have not responded with regards to the permission and assistance sought in the first email. A third email was delivered a week after the second email to the academic staff of public universities that still provided no responses from final year accounting students.

As for the online questionnaire, the questionnaire did not identify the email address of the respondents, thus the respondents remained anonymous. However, at the end of the questionnaire, the respondents were given an option to provide their email address should they want to receive a summary of the final survey results. Two hundred and forty five questionnaires were successfully collected from 10 out of the 14 public universities offering Bachelor of Accountancy program. 


\section{Results and Discussion}

\subsection{Demographic Analysis}

This demographic analysis examines the background profile of the respondents of the study. Table 2 shows the results of the respondents' gender, race and age distribution. The data analysis on gender shows that out of 245 respondents, 53 respondents or $21.63 \%$ of them were male while the other 192 respondents, or $78.37 \%$ were female. Thus, both genders were involved in the study where female was the highest population in the study over male. The data analysis further shows that with regards to race, the majority of respondents were of the Malay race with a total of 178 people and hence representing $72.65 \%$ of the sample. This was followed by the Chinese $(12.2 \%)$, Indians (8.6\%) and the Bumiputera (4.9\%), while 4 people or $1.6 \%$ were others from different race or ethnicity. This distribution suggests that accounting students in Malaysian public universities are Malay dominated. In terms of age, results show that respondents range between 21 and 30 years old. However, 94.69\% consisted of students between 21-24 years old. 238 students are aged 25 years old and below, making up $97.14 \%$ of the sample respondents. This finding suggests that most final year accounting students are those who are in their early to mid-twenties.

Table 2. Demographic Profile on Gender, Race and Age

\begin{tabular}{|c|c|c|c|}
\hline \multicolumn{2}{|c|}{$\begin{array}{c}\text { Demographic Profile } \\
\text { Total = n }\end{array}$} & $\begin{array}{c}\text { Frequency } \\
\mathbf{2 4 5}\end{array}$ & $\begin{array}{c}\text { Percentage (\%) } \\
\mathbf{1 0 0}\end{array}$ \\
\hline Gender & Male & 53 & 21.63 \\
\hline & Female & 192 & 78.37 \\
\hline Race & Malay & 178 & 72.65 \\
\hline & Chinese & 30 & 12.24 \\
\hline & Indian & 21 & 8.57 \\
\hline & Bumiputra & 12 & 4.90 \\
\hline & Others & 4 & 1.63 \\
\hline Age & $21-22$ years old & 122 & 49.80 \\
\hline & $23-24$ years old & 110 & 44.90 \\
\hline & $25-26$ years old & 11 & 4.49 \\
\hline & $27-28$ years old & 1 & 0.41 \\
\hline & $29-30$ years old & 1 & 0.41 \\
\hline
\end{tabular}

Table 3 illustrates the demographic profile on the respondents' year of study, CGPA and internship experience. Results show that a majority of students are Year 3 and Year 4 students, where Year 4 students make up $76.3 \%$ of the total respondents. This is so due to the research instrument being distributed to final year accounting students, as they are the population of interest for this study. This distribution reflects that most university accounting programs have a three to four year duration. The data further illustrates the academic performance of the respondent group, where approximately half of the respondents currently have a CGPA score between 3.01 and 3.50 while $21.6 \%$ of the respondents have a CGPA of above $3.50 .27 .8 \%$ of the respondents recorded a CGPA of below 3.0 but above 2.50. None of the respondents had a CGPA of below 2.50. From the results, $72.2 \%$ of the respondents have a CGPA higher than 3.0 thus it may be concluded that the sample group of this study generally consisted of capable and well-performing accounting students. In terms of having internship experience in a role relating to the accounting field, the results show that the two groups are of roughly the same size, with the internship-experienced group representing a slightly higher proportion of the sample. One hundred and twenty eight students or $52.2 \%$ of the respondents had already had an internship experience before, while the remaining 117 (47.8\%) of the students did not have any internship experience prior to this study.

Table 3. Demographic Profile on Year of Study, CGPA and Internship Experience

\begin{tabular}{|c|c|c|c|}
\hline $\begin{array}{c}\text { Demographic } \\
\text { Profile }\end{array}$ & Profile & Frequency & $\begin{array}{c}\text { Percentage } \\
(\%)\end{array}$ \\
\hline Year of study & Year 1 & 0 & 0.0 \\
\hline & Year 2 & 0 & 0.0 \\
\hline & Year 3 & 58 & 23.7 \\
\hline CGPA & Year 4 & 187 & 76.3 \\
\hline & $2.00-2.50$ & 0 & 0.0 \\
\hline & $3.51-3.00$ & 68 & 27.8 \\
\hline & $3.51-4.50$ & 124 & 50.6 \\
\hline $\begin{array}{c}\text { Internship } \\
\text { experience }\end{array}$ & Yes & 53 & 21.6 \\
\hline & No & 117 & 52.2 \\
\hline
\end{tabular}

\subsection{Job Prospect Belief}

Table 4. Mean and Standard Deviation Scores of Students' Job Prospect Beliefs

\begin{tabular}{|l|c|c|c|}
\hline Statement & Mean & Median & $\begin{array}{c}\text { Std. } \\
\text { Deviation }\end{array}$ \\
\hline $\begin{array}{l}\text { A professional membership } \\
\text { will allow me to attain higher } \\
\text { salary }\end{array}$ & 4.44 & 5.00 & 0.70 \\
\hline $\begin{array}{l}\text { Having a professional } \\
\text { qualification is associated with } \\
\text { better career development } \\
\text { opportunities }\end{array}$ & 4.64 & 5.00 & 0.57 \\
\hline $\begin{array}{l}\text { A professional membership is } \\
\text { important to ensure job stability }\end{array}$ & 4.33 & 4.00 & 0.75 \\
\hline $\begin{array}{l}\text { A professional membership is } \\
\text { important to ensure job security }\end{array}$ & 4.32 & 4.00 & 0.75 \\
\hline $\begin{array}{l}\text { I am more marketable if I have } \\
\text { a professional qualification }\end{array}$ & 4.59 & 5.00 & 0.60 \\
\hline $\begin{array}{l}\text { Average score for all } \\
\text { statements }\end{array}$ & $\mathbf{4 . 4 6}$ & $\mathbf{4 . 6 0}$ & $\mathbf{0 . 6 7}$ \\
\hline
\end{tabular}

Table 4 depicts the descriptive statistics for the students' job prospect beliefs. Based on the six statements, on 
average, the respondents agreed that having a professional membership can lead to better job prospects in the future $(\mathrm{M}=4.46)$. According to the individual statements, respondents appear to most agree with the statement that having a professional qualification can lead to better career development opportunities $(\mathrm{M}=4.64)$. Overall, the respondents generally agreed to all the statements relating to job prospects, as reflected by the mean score for each statement which lies above the score of four (4).

\subsection{Social Belief}

Table 5 depicts the descriptive statistics for the students' social beliefs. Based on the four statements, on average, the respondents generally agreed that social influences are associated with having or pursuing a professional membership (M=4.04). Respondents most agree with the statement that having a professional qualification will make them more valuable $(\mathrm{M}=4.22)$. The statistics also indicate that the respondents strongly perceive that important figures around them believe they should pursue a qualification $(\mathrm{M}=4.15)$. The respondents appear to take a more neutral take on statements that relate to social establishments, as reflected by the lower mean scores for statements 1 and 3 ( $M=3.89$ for both statements).

Table 5. Mean and Standard Deviation Scores of Students' Social Beliefs

\begin{tabular}{|l|c|c|c|}
\hline Statement & Mean & Median & $\begin{array}{c}\text { Std. } \\
\text { Deviation }\end{array}$ \\
\hline $\begin{array}{l}\text { A professional qualification will } \\
\text { give me a higher social status } \\
\text { and respect among my peers } \\
\text { and relevant others }\end{array}$ & 3.89 & 4.00 & 0.89 \\
\hline $\begin{array}{l}\text { A professional qualification will } \\
\text { make me a valuable employee }\end{array}$ & 4.22 & 4.00 & 0.77 \\
\hline $\begin{array}{l}\text { A professional qualification will } \\
\text { makeme important in my } \\
\text { community }\end{array}$ & 3.89 & 4.00 & 0.86 \\
\hline $\begin{array}{l}\text { People important to me (e.g. } \\
\text { parents, teachers, relatives, } \\
\text { peers, accounting professionals) } \\
\text { think I should pursue a } \\
\text { professional qualification }\end{array}$ & 4.15 & 4.00 & 0.86 \\
\hline $\begin{array}{l}\text { Average score for all } \\
\text { statements }\end{array}$ & $\mathbf{4 . 0 4}$ & $\mathbf{4 . 0 0}$ & $\mathbf{0 . 8 4}$ \\
\hline
\end{tabular}

\subsection{Capability Belief}

Table 6 depicts the descriptive statistics for the students' capability beliefs. Based on the four statements, on average, the respondents reported a mean score of $\mathrm{M}=3.83$ with regards to their belief in their capabilities to attempt working towards a professional qualification. The students most agree with regards to their belief that they have the mental fortitude to work towards the attainment of a professional membership $(\mathrm{M}=3.91)$. The other individual statements also record close mean scores where the lowest mean score was recorded for the statement relating to students' belief in their current knowledge and skill set
$(\mathrm{M}=3.71)$.

Table 6. Mean and Standard Deviation Scores of Students' Capability Beliefs

\begin{tabular}{|l|c|c|c|}
\hline Statement & Mean & Median & $\begin{array}{c}\text { Std. } \\
\text { Deviation }\end{array}$ \\
\hline $\begin{array}{l}\text { I believe I have what it } \\
\text { takes to become } \\
\text { professional accountant }\end{array}$ & 3.85 & 4.00 & 0.87 \\
\hline $\begin{array}{l}\text { I believe have the mental } \\
\text { fortitude to work towards } \\
\text { the attainment of a } \\
\text { professional membership }\end{array}$ & 3.91 & 4.00 & 0.87 \\
\hline $\begin{array}{l}\text { I believe I have the } \\
\text { necessary knowledge to } \\
\text { facilitate me to become a } \\
\text { professional accountant }\end{array}$ & 3.71 & 4.00 & 0.85 \\
\hline $\begin{array}{l}\text { My experience in } \\
\text { accounting related work } \\
\text { can help me in becoming } \\
\text { a professional accountant }\end{array}$ & 3.85 & 4.00 & 0.95 \\
\hline $\begin{array}{l}\text { Average score for all } \\
\text { statements }\end{array}$ & $\mathbf{3 . 8 3}$ & $\mathbf{4 . 0 0}$ & $\mathbf{0 . 8 8}$ \\
\hline
\end{tabular}

\subsection{Preference}

Table 7 illustrates the descriptive statistics for the students' preference for a professional qualification. Based on the four statements, on average, the respondents generally agreed that they preferred to have a professional qualification due to reasons such as a professional membership will allow them to be better off, complement their personal goals and facilitate their desire to work in the accounting field (M=4.06). The least agreed statement was the statement four (4) which measured whether students wanted to do the professional qualification for the satisfaction of having a challenging pursuit $(\mathrm{M}=3.99)$.

Table 7. Mean and Standard Deviation Scores of Students' Preference

\begin{tabular}{|l|c|c|c|}
\hline Statement & Mean & Median & $\begin{array}{c}\text { Std. } \\
\text { Deviation }\end{array}$ \\
\hline $\begin{array}{l}\text { Professional membership } \\
\text { would make me better off }\end{array}$ & 4.10 & 4.00 & 0.70 \\
\hline $\begin{array}{l}\text { Professional membership } \\
\text { will complement my } \\
\text { self-actualized goal }\end{array}$ & 4.07 & 4.00 & 0.79 \\
\hline $\begin{array}{l}\text { I would love to work in an } \\
\text { audit firm or an accounting } \\
\text { department of any } \\
\text { institution of an }\end{array}$ & 4.09 & 4.00 & 0.93 \\
\hline $\begin{array}{l}\text { I like the challenge of } \\
\text { pursuing a professional } \\
\text { qualification }\end{array}$ & 3.99 & 4.00 & 0.89 \\
\hline $\begin{array}{l}\text { Average score for all } \\
\text { statements }\end{array}$ & $\mathbf{4 . 0 6}$ & $\mathbf{4 . 0 0}$ & $\mathbf{0 . 8 3}$ \\
\hline
\end{tabular}

\subsection{Constraints}

Table 8 illustrates the descriptive statistics for the perceived constraints if respondents were to pursue a professional qualification. Based on the six (6) statements, the respondents appear to approximately agree that there 
are constraints associated with the pursuance of a professional membership ( $\mathrm{M}=3.84)$. On an individual basis, respondents most highly agreed with the statement that the professional exams are too costly $(M=4.37)$. The statement that was least agreed was statement six (6) which had suggested that difficulty in maintaining the membership was a constraint $(\mathrm{M}=3.53)$.

Table 8. Mean and Standard Deviation Scores of Students' Constraints

\begin{tabular}{|l|c|c|c|}
\hline Statement & Mean & Median & $\begin{array}{c}\text { Std. } \\
\text { Deviation }\end{array}$ \\
\hline $\begin{array}{l}\text { It takes too long to obtain a } \\
\text { professional membership }\end{array}$ & 3.82 & 4.00 & 0.92 \\
\hline $\begin{array}{l}\text { The professional exams are } \\
\text { too costly for me }\end{array}$ & 4.37 & 5.00 & 0.79 \\
\hline $\begin{array}{l}\text { I believe the professional } \\
\text { exams are too difficult for } \\
\text { me to pass }\end{array}$ & 3.90 & 4.00 & 0.96 \\
\hline Lack of reading materials & 3.77 & 4.00 & 0.98 \\
\hline $\begin{array}{l}\text { The process of attaining the } \\
\text { membership is too } \\
\text { cumbersome and inflexible }\end{array}$ & 3.65 & 4.00 & 0.98 \\
\hline $\begin{array}{l}\text { I believe that it is too } \\
\text { difficult to maintain the } \\
\text { professional membership }\end{array}$ & 3.53 & 4.00 & 1.00 \\
\hline $\begin{array}{l}\text { Average score for all } \\
\text { statements }\end{array}$ & $\mathbf{3 . 8 4}$ & $\mathbf{4 . 1 7}$ & $\mathbf{0 . 9 4}$ \\
\hline
\end{tabular}

Table 9. Mean and Standard Deviation Scores of Students' Intention to Pursue a Professional Qualification

\begin{tabular}{|l|c|c|c|}
\hline Statement & Mean & Median & $\begin{array}{c}\text { Std. } \\
\text { Deviation }\end{array}$ \\
\hline $\begin{array}{l}\text { It is important for me to be an } \\
\text { accounting professional }\end{array}$ & 4.27 & 4.00 & 0.81 \\
\hline $\begin{array}{l}\text { I am willing to work hard to } \\
\text { make my accounting } \\
\text { profession successful }\end{array}$ & 4.32 & 4.00 & 0.74 \\
\hline $\begin{array}{l}\text { I believe that a professional } \\
\text { accounting career will be } \\
\text { satisfying }\end{array}$ & 4.22 & 4.00 & 0.80 \\
\hline $\begin{array}{l}\text { Accounting is a great } \\
\text { profession to be associated } \\
\text { with }\end{array}$ & 4.26 & 4.00 & 0.78 \\
\hline $\begin{array}{l}\text { I intend to be a member of at } \\
\text { least one professional } \\
\text { accounting body }\end{array}$ & 4.22 & 4.00 & 0.89 \\
\hline $\begin{array}{l}\text { I believe that accounting is an } \\
\text { ideal profession }\end{array}$ & 4.18 & 4.00 & 0.82 \\
\hline $\begin{array}{l}\text { I am proud to tell others that I } \\
\text { am part of the accounting } \\
\text { profession }\end{array}$ & 4.43 & 5.00 & 0.75 \\
\hline $\begin{array}{l}\text { I am willing to change values } \\
\text { to those suitable to the } \\
\text { accounting profession }\end{array}$ & 4.08 & 4.00 & 0.79 \\
\hline $\begin{array}{l}\text { Average score for all } \\
\text { statements }\end{array}$ & $\mathbf{4 . 2 5}$ & $\mathbf{4 . 1 3}$ & $\mathbf{0 . 8 0}$ \\
\hline
\end{tabular}

Table 9 depicts the descriptive statistics for accounting students' intention to pursue a professional qualification. This is the dependent variable of the study. Based on the eight (8) statements, the respondents on average agreed that they are keen and committed to have a professional membership $(M=4.25)$. According to the individual statements, respondents appear to most agree with the statement that they would be proud to tell others that they are part of the professional accountant profession $(\mathrm{M}=4.43)$. This is followed by statement two (2) that records willingness of respondent to work hard to have a successful accounting career $(\mathrm{M}=4.32)$. Overall, the respondents generally agreed that they would like to commit towards obtaining a professional membership as all the mean scores for each individual statement was above four (4).

\subsection{Correlation Analysis between Belief Factors (B) and Students' Intention}

Table 10 shows the correlation results between the three belief factors and the students' intention to pursue a professional qualification. For the job prospect belief and social belief, results indicate that there is a significant, positive but weak correlation between the two variables and the students' intention to pursue a professional qualification $(\mathrm{r}=.481, \mathrm{p}<.001 ; \mathrm{r}=.426, \mathrm{p}<.001)$. For capability beliefs, there is a significant, positive and moderate correlation between the capability belief and intention to pursue a professional qualification $(\mathrm{r}=.553, \mathrm{p}$ $<.001)$.

Table 10. Summary Statistics of the Correlation Analysis between Students' Intention to Pursue a Professional Qualification and Students' Beliefs

\begin{tabular}{|c|c|c|}
\hline \multirow{2}{*}{ Variable } & \multicolumn{2}{|c|}{$\begin{array}{c}\text { Students' Intention to Pursue a } \\
\text { Professional Qualification }\end{array}$} \\
\cline { 2 - 3 } & $\begin{array}{c}\text { Pearson Coefficient of } \\
\text { Correlation }(\boldsymbol{r})\end{array}$ & $\boldsymbol{p}$-value \\
\hline $\begin{array}{c}\text { Job prospect beliefs } \\
\text { towards the professional } \\
\text { qualification }\end{array}$ & .481 & $.000^{* *}$ \\
\hline $\begin{array}{c}\text { Social beliefs towards the } \\
\text { professional qualification }\end{array}$ & .426 & $.000^{* *}$ \\
\hline $\begin{array}{c}\text { Capability beliefs towards } \\
\text { the professional } \\
\text { qualification }\end{array}$ & .553 & $.000^{* *}$ \\
\hline
\end{tabular}

\subsection{Correlation between Preference Factor $(P)$ and Students' Intention}

Table 11 shows the correlation analysis result between the preference factor and the students' intention to pursue a professional qualification. There is a significant, positive and moderate correlation between students' preference and their intention to pursue the qualification $(r=.651, p$ $<.001)$.

Table 11. Summary Statistics of the Correlation Analysis between Students' Intention to Pursue a Professional Qualification and Students' Preference

\begin{tabular}{|c|c|c|}
\hline \multirow{2}{*}{ Variable } & \multicolumn{2}{|c|}{$\begin{array}{c}\text { Students' Intention to Pursue a } \\
\text { Professional Qualification }\end{array}$} \\
\cline { 2 - 3 } & $\begin{array}{c}\text { Pearson Coefficient of } \\
\text { Correlation }(\boldsymbol{r})\end{array}$ & $\boldsymbol{p}$-value \\
\hline $\begin{array}{c}\text { Preference to hold a } \\
\text { professional qualification }\end{array}$ & .651 & $.000^{* *}$ \\
\hline
\end{tabular}




\subsection{Correlation between Constraint Factor (C) and Students' Intention}

Table 12 shows the results of the correlation analysis between the constraint factor and the students' intention to pursue a professional qualification. Results indicate that there is an insignificant, negative and very weak correlation between constraint faced by student and their intention to pursue the qualification $(r=-.056, \mathrm{p}>.005)$.

Table 12. Summary Statistics of the Correlation Analysis between Students' Intention to Pursue a Professional Qualification and Students'

\begin{tabular}{|c|c|c|}
\hline \multirow{2}{*}{ Variable } & $\begin{array}{c}\text { Students' Intention to Pursue a } \\
\text { Professional Qualification }\end{array}$ \\
\cline { 2 - 3 } & $\begin{array}{c}\text { Pearson Coefficient } \\
\text { of Correlation }(\boldsymbol{r})\end{array}$ & $\boldsymbol{p}$-value \\
\hline $\begin{array}{c}\text { Constraints in attaining the } \\
\text { professional qualification }\end{array}$ & -.056 & .386 \\
\hline
\end{tabular}

\subsection{Multiple Regression Analysis}

Prior to performing the multiple regression analysis, a one way ANOVA was carried out to determine the overall significance of the model. The results of F-test will indicate whether there is a linear relationship between all the independent variables (when considered together) with the dependent variable. Table 13 summarizes the result of the one-way ANOVA test, where the F-ratio result is $F_{(5,239)}=$ $51.586, \mathrm{p}<.001$. This indicates that there is a significant linear relationship between students' intention to pursue a professional qualification and at least one of the five independent variables tested in the model. In other words, at least one of either job prospects belief, social belief, capability belief, preference or constraints, will have an effect on students' intention to pursue a professional qualification.

Further, with reference to Table 14 , the $\mathrm{R}^{2}=.519$, which means that the model explains approximately $51.9 \%$ of the total variation in the dependent variable. This indicates that $51.9 \%$ of the variation in students' intention to pursue an accounting professional qualification was explained by the variation in beliefs towards the professional qualification, preference to hold a professional qualification, and constraints faced in attaining the professional qualification. The model is thus overall considered significant and appropriate.

Following the tests of goodness of fit, the multiple linear regression was carried out to test the hypotheses of this study. Table 15 depicts the coefficient results of the multiple linear regression analysis carried out on the model.

Table 13. Summary Statistics of the One Way ANOVA for BPC factors

\begin{tabular}{|c|c|c|c|c|c|c|}
\hline \multicolumn{2}{|c|}{ Model } & Sum of Squares & df & Mean Square & F & Sig. \\
\hline \multirow{3}{*}{1} & Regression & 46.151 & 5 & 9.230 & 51.586 & .000 \\
\cline { 2 - 7 } & Residual & 42.764 & 239 & .179 & & \\
\cline { 2 - 7 } & Total & 88.916 & 244 & & & \\
\hline \multicolumn{2}{l}{ a. Dependent Variable: ProfQual } \\
b. Predictors: (Constant), JobprosB, SocB, CapB, Pref, Constr \\
\hline
\end{tabular}

Table 14. Summary Statistics of the $\mathrm{R}^{2}$ of Multiple Regression Model

\begin{tabular}{|c|c|c|c|c|c|c|c|c|c|}
\hline \multirow{2}{*}{ Model } & \multirow{2}{*}{$\mathbf{R}$} & \multirow{2}{*}{ R Square } & \multirow{2}{*}{ Adjusted R Square } & \multirow{2}{*}{$\begin{array}{l}\text { Std. Error of the } \\
\text { Estimate }\end{array}$} & \multicolumn{5}{|c|}{ Change Statistics } \\
\hline & & & & & R Square Change & F Change & df1 & df 2 & Sig. F Change \\
\hline 1 & .720 & .519 & .509 & .42300 & .519 & 51.586 & 5 & 239 & .000 \\
\hline \multicolumn{10}{|c|}{ a. Dependent Variable: ProfQual } \\
\hline b. Prec & ors: & onstant & JobprosB, SocB, Ca & Pref, Constr & & & & & \\
\hline
\end{tabular}

Table 15. Summary Statistics of Multiple Regression Result of BPC Factors

\begin{tabular}{|c|c|c|c|c|c|c|}
\hline & \multirow{2}{*}{ Model } & \multicolumn{2}{|c|}{ Unstandardized Coefficients } & \multirow{2}{*}{$\begin{array}{c}\begin{array}{c}\text { Standardized } \\
\text { Coefficients }\end{array} \\
\text { Beta } \\
\end{array}$} & \multirow{2}{*}{$\mathbf{t}$} & \multirow{2}{*}{ Sig. } \\
\hline & & B & Std. Error & & & \\
\hline \multirow{6}{*}{1} & (Constant) & .887 & .283 & & 3.138 & .002 \\
\hline & Job prospect belief & .254 & .063 & .221 & 4.011 & .000 \\
\hline & Social belief & .244 & .055 & .246 & 3.802 & .000 \\
\hline & Capability belief & .207 & .047 & .250 & 4.421 & .000 \\
\hline & Preference & .372 & .058 & .385 & 6.376 & .000 \\
\hline & Constraint & -.066 & .040 & -.077 & -1.643 & .102 \\
\hline
\end{tabular}

a. Dependent Variable: ProfQual 
Based on the results, it was found that four out of five of the independent variables tested had a significant influence on the dependent variable. All three belief factors, namely the job prospect belief $\left(\beta_{1}=.254, \mathrm{t}=4.011, p<.001\right)$, social belief $\left(\beta_{2}=.244, \mathrm{t}=3.802, p<.001\right)$ and capability belief $\left(\beta_{3}=.207, \mathrm{t}=4.421, p<.001\right)$, as well as the preference factor $\left(\beta_{4}=.372, \mathrm{t}=6.376, p<.001\right)$, positively and significantly influenced accounting students' intention to pursue a professional qualification upon their graduation. This signifies that increase in students' beliefs with regards to the positive job prospects that comes with a professional qualification, increase in students' social beliefs that professional qualifications are needed, increase in students' belief in their own capability and increase in students' own preference to hold a professional qualification would all in turn increase the students' intention to pursue the qualification. In contrast, results of the regression model show that the constraint factor had no significant relationship with the students' intention to pursue the qualification $\left(\beta_{5}=-.066, \mathrm{t}=-1.643, \mathrm{p}=.102\right)$, thus reflecting that albeit the student facing more (or less) constraints in his pursuit towards attaining a professional qualification, the student's intention would not be significantly affected.

The weightage of the independent variables (i.e. the BPC factors) that influenced the dependent variable was indicated by the coefficient or the beta-values, $\beta_{i}$ of each independent variable. The significant factor that had the highest beta-value is preference factor with a coefficent of $\beta_{4}=.372$. This is followed by job prospect belief $\left(\beta_{1}=.254\right)$, social belief $\left(\beta_{2}=.244\right)$ and capability belief $\left(\beta_{3}=.207\right)$. This reflects that students' preference had the most significant impact on the students' intention as compared to the other factors.

\subsection{Discussion of Findings}

The main objective of this study was to determine the significant factors that influence accounting students' intention to pursue a professional qualification. The BPC model under the BDT suggested that there are three main factors that underlie ones' decision-making process and thus his subsequent behaviour. The BPC model predicts that while the individual's positive beliefs and preference for the behaviour may spur one towards it, the ultimate decision made may be hindered by the resource constraints faced by the individual in carrying out the behaviour.

In line with the BPC-BDT, the first objective of this study was to determine whether beliefs about the accounting professional qualification would subsequently influence accounting students' intention to pursue the qualification or not. Students' job prospect beliefs, social beliefs and capability beliefs were examined to proxy for the belief component of the BPC model by testing $\mathrm{H}_{1}, \mathrm{H}_{2}$ and $\mathrm{H}_{3}$ respectively.

Results for all three hypotheses (i.e. H1, H2 and H3) were significantly positive, reflecting that beliefs of the accounting students in Malaysian public universities significantly influence their intention to pursue the qualification. The positive correlation reflects that the greater the positive beliefs towards having a qualification, the greater the intention would be to pursue it. The coefficient of the regression analysis further indicate that job prospect beliefs $\left(\beta_{1}=.254 ; \mathrm{M}=4.46\right)$ are most highly weighted by the students, followed by social beliefs $\left(\beta_{2}=.244 ; \mathrm{M}=4.04\right)$ and lastly capability beliefs $\left(\beta_{3}=.207\right.$; $M=3.83$ ). This suggests that in considering whether to pursue the professional qualification, Malaysian accounting students are most affected by their beliefs that the qualification can provide with better career opportunities and benefits. The finding here is not surprising as it is supported by a number of previous literature which have found similar results (e.g. Felton et al., 1994; Ahmed et al., 1997, Tan \& Laswad, 2006; Sugahara \& Boland, 2009; Jackling \& Keneley, 2009; Mustapha \& Hassan, 2012; Aziz et al., 2017, Owusu et al., 2018).

The results reflect that accounting students in Malaysia are aware that those with professional qualifications are in demand by the industry, thus encouraging them to consider taking up the exams so as to ensure job security, stability, marketability and overall better job prospects. Malaysia, in particular, is aiming to have at least 60,000 professional accountants by 2020 , hence reflecting the high industry demand and career opportunities open for those with qualifications (ACCA Global, 2018). Given that approximately $77 \%$ of respondents in this study are of the Malay race or of Bumiputra ethnicity, the results of this study are also further in line with the findings of Aziz et al. (2017), who previously reported that job security and job stability are the most significant factors considered by Bumiputra accounting students.

As for social beliefs, the overall results support the notion that important social interactions and other social perceptions have significant influences on one's behavior and decision making process. Here, the findings indicate that respondents particularly placed high regard on the opinion of important people to them such as parents, relatives, teachers and peers, hence can significantly influence their intention and decision of whether to pursue a career as a professional accountant or not. This is consistent with studies such as that by Djatej et al. (2015), Ahmad et al. (2015) and Tan and Laswad (2006), which similarly found that parental influence as well as advice or encouragement from other significant people can ultimately lead to the students having a more positive attitude towards the accounting career. The significance of social beliefs as a factor in determining students' intention is one that can even be deemed as expected, given that Malaysia, as a South Asian country, generally values familial opinions more than their Western counterparts (Auyeung \& Sands, 1997; Law \& Yuen, 2012).

In terms of the capability belief, results for hypothesis (H3) indicate that belief in one's own abilities, or also 
referred to as self-efficacy (Bandura, 1986), is a significant predictor of his decisions to pursue an intended goal. This is consistent with findings from studies such as those by Felton et al. (1994), Ahmed et al. (1997), Auyeung and Sands (1997), Hayes and Credle (2008), Schoenfeld et al. (2017) and Owusu et al. (2018). The results thus suggest that the accounting students' perception of their personal capabilities is important to determine their future course and career pathways. Likewise, the results indirectly imply that those performing academically well are more likely to have an intention to pursue the qualification. This is understandable given that professional qualifications such as the ICAEW, MICPA, ACCA and the CPA are all highly challenging pursuits, which will require a certain degree of learning capability besides also demanding continuous time and effort from the students. The findings may suggest that in order to encourage students to pursue the professional qualifications, it is important to prepare them not only in terms of having sufficient accounting knowledge and skill sets, but it would be just as important to develop their mental fortitude and build confidence of their potential.

The second objective of this study was to determine whether preferences for the accounting professional qualification influence the accounting students' intention to pursue the qualification. Results of hypothesis (H4) show that relative to the other factors, the preference factor is actually the most significant determinant of students' intention to pursue the qualifications $\left(\beta_{4}=.372, \mathrm{M}=4.06\right)$, henceforth indicating that the greater the students' preference to hold a qualification, the stronger would be their intention to pursue one. The significant and positive relationship between preference and intention to pursue is consistent with a number of similar findings in extant accounting education literature (Jackling et al., 2006; Sugahara et al., 2008; Sugahara and Boland, 2009; Tan \& Laswad, 2006; Owusu et al., 2018). Further, this finding strongly supports the results of a similar study by Ahmad et al. (2015) which was also carried out in the Malaysia context, where it was reported that intrinsic interest is the most significant factor that explains students' intention to pursue professional qualifications as compared to other financial factors.

To highlight, this study's findings with regards to students' preference provide support to the notion that the accounting students of today tend to attach greater importance to their intrinsic interests and preference when deciding their career pathway. This is in contrast with many of the earlier studies, which tend to report that students were significantly more motivated by the expected financial incentives instead of their own personal interests in the accounting field (Gul et al, 1989; Ahmed et al, 1997). Hence, this finding highlights that to encourage today's students towards pursuing a professional qualification, it may not be enough to rely solely on providing extrinsic benefits, but instead education institutions or companies should also market the professional qualifications as an interesting career pathway in order to attract the best talents.

The final objective of this study was to examine whether the constraints to attaining the accounting professional qualification influence students' intention to pursue the qualification. Constraints tested in this study were indicated by several constructs, namely the time taken to obtain a professional membership, difficulty of exams, difficulty to pass the exams, the lacking of study materials, the inflexibility of the process of attaining membership and the difficulty to maintain the membership. The findings in this study found that the hypothesis $\left(\mathrm{H}_{5}\right)$ was not supported, or in other words, there is no significant relationship between the constraints faced and the student's intention to pursue a professional qualification $\left(\beta_{5}=-.066, \mathrm{p}=.102\right.$, $\mathrm{M}=3.84$ ).

Unlike the other factors tested in this study, this constraint factor reported a negative relationship with the intention to pursue, which is in the expected direction and consistent with the understanding that facing such constraints may, right from the start, deter some accounting students from even having any intention to pursue a professional qualification. Nevertheless, the findings of $\mathrm{H}_{5}$ suggest that given that the student already expects to face issues such as cost, time, resource or capability constraints, these factors may still not significantly deter the student's intention from attempting to pursue a professional qualification. The results here are similar to that of Owusu et al. (2018), whom also reported that constraint factors are insignificant to explain Ghanaian accounting students' intention to pursue a CPA qualification. In contrast, other studies, however, had found that similar constraints could prevail as significant deterrents in one's pursuit towards a professional qualification (Aziz et al., 2017).

Several explanations may be suggested to explain this difference in observation. A reason could be that the respondents of this study, namely the final year accounting students in Malaysian public universities, who are all still yet to graduate, may still not have an in-depth understanding of the significance of the constraints that they are to face given that they actually attempt to pursue a professional qualification after graduating. It is possible that the respondents are still acutely unaware of the high financial costs associated with the process of obtaining the qualification. In this day and age, it is generally more expected that having insufficient financial support can be a major hindrance for one to actually pursue the qualification, albeit having strong ambitions to do so. Another possible reason for the insignificance of the results could be due to students' high confidence in their capabilities, which outweighs constraints assessed such as difficulty in passing exams. This can be supported by the demographic profile of the respondents in this study, where approximately half of the students have a CGPA of above 3.0 while approximately $21 \%$ of the respondents have a CGPA of 
above 3.50 .

Overall, the results of this study provide evidence that suggest that job prospect beliefs, social beliefs, capability beliefs and personal preference have significant influence on accounting students' intention to pursue a professional qualification and potentially, their subsequent decision to actually pursue the exams. Preference appears to be the most important factor to the respondents. Expected constraints, such as limitations in time and money, however, appear to not significantly dissuade the students from their intention.

\section{Conclusions}

This study aims to explore the factors that influence Malaysian accounting students' intention to pursue a professional qualification. This study shows that there was a significant and positive relationship between all three belief components and the students' intention to pursue the qualifications. Job prospect belief appeared to be most highly weighted among the three components, followed closely by social beliefs and capability beliefs. Apart from achieving extrinsic benefits, results in this study indicated that social belief is also a significant factor that contributes to students' intention. This includes them believing that a professional qualification can make the respondent more valuable and respectable, as well as believing that important figures such as parents and teachers encouraged pursuing a professional qualification. Interestingly, this finding is similar especially to studies that primarily used by Asian students as respondents such as that by Auyeung and Sands (1997), which thus suggests that Asian students still highly value familial and educator's opinions, and are relatively more cautious of their standings in society.

This study also shows that students' preference or intrinsic interest to hold a qualification is the most significant out of the five variables examined. Other recent studies have also supported the notion that the younger generation of students today appear to take personal interest as a main factor in choosing career pathways (Ahmad et al., 2015; Owusu et al., 2018), which is in contrast to earlier accounting career studies which reported that students tended to value extrinsic interests more. This study also shows that similar to Owusu et al. (2018), the findings in this study also found a negative but insignificant relationship for the constraint factor. In essence, this finding suggests that the strength of Malaysian accounting students' intention to pursue a qualification will hardly differ regardless of the difficulties they faced. Nevertheless, it may be highlighted here that this study measured students' intentions per se, and not the students' actual enrolment into any professional programs. Thus, albeit being an insignificant factor at this stage, the results should be interpreted with caution as such constraints may prove to be more significant at later stages of students' career decision making process.

The main contribution of this study is that the findings provide valuable supporting evidence of the main factors that influence Malaysian accounting students' intentions to pursue a professional qualification, thus contributes to the accounting education literature in Malaysia, which is still relatively lacking as compared to those carried out in the context of Western or more developed countries. This study also contributes to accounting literature by applying the BPC-BDT to explore decision making and people's behavior. Prior career-related studies have primarily used other theoretical frameworks such as the TRA and TPB.

\section{Acknowledgements}

We wish to thank the Institute of Quality and Knowledge Advancement and the Institute of Research Management and Innovation of Universiti Teknologi for their support and funding.

\section{REFERENCES}

[1] ACCA Global. (2016). Professional accountants - the future: Drivers of change and future skills. Retrieved from https://www.accaglobal.com

[2] Ahmad, Z., Ismail, H., \& Anantharaman, R. N. (2015). To be or not to be: an investigation of accounting students' career intentions. Education+ Training, 57(3), 360-376

[3] Ahmed, K., Alam, K. F., \& Alam, M. (1997). An empirical study of factors affecting accounting students' career choice in New Zealand. Accounting Education, 6(4), 325-335

[4] Ajzen, I. (1991). The theory of planned behavior. Organizational behavior and human decision processes, 50(2), 179-211.

[5] Ajzen, I., \& Fishbein, M. (1980). Understanding attitudes and predicting social behavior. Englewood Cliffs, NJ: Prentice-Hall.

[6] Albrecht, W. S., \& Sack, R. J. (2000). Accounting education: Charting the course through a perilous future (Vol. 16). Sarasota, FL: American Accounting Association.

[7] Amabile, T. M., Hill, K. G., Hennessey, B. A., \& Tighe, E. M. (1994). The work preference inventory: Assessing intrinsic and extrinsic motivational orientations. Journal of Personality and Social Psychology, 66(5), 950-967.

[8] Aziz, D. A., Ibrahim, M. A., Sidik, M. H. J., \& Tajuddin, M. (2017). Accounting Students' Perception and Their Intention to Become Professionally Qualified Accountants. In SHS Web of Conferences (Vol. 36, p. 00008). EDP Sciences.

[9] Auyeung, P., \& Sands, J. (1997). Factors influencing accounting students' career choice: a cross-cultural validation study. Accounting Education, 6(1), 13-23. 
[10] Bandura, A. (1989). Human agency in social cognitive theory. American psychologist, 44(9), 1175

[11] Bauder, H. (2006). Labor movement: How migration regulates labor markets. Oxford University Press.

[12] Brown, S. D., Lent, R. W., Telander, K., \& Tramayne, S. (2011). Social cognitive career theory, conscientiousness, and work performance: A meta-analytic path analysis. Journal of Vocational Behavior, 79(1), 81-90.

[13] Carpenter, C. G., \& Strawser, R. H. (1970). Job selection preferences of accounting students. Journal of Accountancy, 129(6), 84-86.

[14] Djatej, A., Chen, Y., Eriksen, S., \& Zhou, D. (2015). Understanding students' major choice in accounting: an application of the theory of reasoned action. Global Perspectives on Accounting Education, 12, 53.

[15] Felton, S., Buhr, N., \& Northey, M. (1994). Factors influencing the business student's choice of a career in chartered accountancy. Issues in Accounting education, 9(1), 131.

[16] Ghani, E. K., Said, J., Nasir, N. M., \& Jusoff, K. (2008). The 21 st century accounting career from the perspective of the Malaysian university students. Asian Social Science, 4(8), 73-83

[17] Ghani, E. K., \& Said, J. (2009). A Comparative Study on Malay and Chinese Accounting Students' Perceptions on Accounting Career. Canadian Social Science, 5(3), 1.

[18] Gul, F.A., Andrew, B.H., Leong, S.C. and Ismail, Z. (1989) Factors influencing choice of discipline of study-accountancy, engineering, law and medicine, Accountant and Finance 29(2), 93-101

[19] Hayes, Z. A., \& Credle, S. H. (2008). An application of social cognitive career theory: exploring factors influencing the decision to select public accounting as a career choice. International Journal of Business Research, 8(5), 53-63.

[20] Jaffar, N., Ismail, N. , \& Md Zahid, S. (2015). Determinants of the accounting students' preference International Journal of. Finance and Accounting, 6(2), 59-65.

[21] Jackling, B., \& Calero, C. (2006). Influences on undergraduate students' intentions to become qualified accountants: Evidence from Australia. Accounting Education: an international journal, 15(4), 419-438.

[22] Jackling, B., \& Keneley, M. (2009). Influences on the supply of accounting graduates in Australia: a focus on international students. Accounting \& Finance, 49(1), 141-159.

[23] Kurschner, T. (2018). Korn Ferry study reveals global talent shortage could threaten business growth around the world. Retrieved from https://www.kornferry.com/press/korn-ferry-study-revealsglobal-talent-shortage-could-threaten-business-growth-aro und-the-world

[24] Law, P. K. (2010). A theory of reasoned action model of accounting students' career choice in public accounting practices in the post-Enron. Journal of Applied Accounting Research, 11(1), 58-73

[25] Law, P., \& Yuen, D. (2012). A multilevel study of students' motivations of studying accounting: implications for employers. Education+ Training, 54(1), 50-64

[26] Lee, M.K. (2018). The drive to double Malaysia's accountancy profession by 2020. Retrieved from https://www.accaglobal.com/pk/en/member/member/accou nting-business/2018/03/practice/malaysia-2020.html

[27] Monga, V. (2017). As Regulations Change, Companies Grapple with Accountant Shortage. Wall Street Journal Online Edition, p. 1.

[28] Muhamad, H., Salleh, M. M., \& Nordin, M. S. M. (2016) Factors influencing career choice of accounting students in University Putra Malaysia: Qualitative pilot study. Journal of Advanced Research in Social and Behavioural Sciences, 5(1), 25-34.

[29] Mustapha, M., \& Hassan, M. H. A. (2012). Accounting Students' Perception on Pursuing Professional Examination. International Journal of Education, 4(4), 1.

[30] Nasir, N. M., Ghani, E. K., \& Said, J. (2009). Why do not accounting graduates want to become accountants? Journal of Modern Accounting and Auditing, 5(5), 59.

[31] Owusu, G. M. Y., Obeng, V. A., Ofori, C. G., Ossei Kwakye, T., \& Bekoe, R. A. (2018). What explains student's intentions to pursue a certified professional accountancy qualification?. Meditari Accountancy Research, 26(2), 284-304.

[32] Pasewark, W. R., \& Viator, R. E. (2006). Sources of work-family conflict in the accounting profession. Behavioral Research in Accounting, 18(1), 147-165.

[33] Sugahara, S., \& Boland, G. (2009). The accounting profession as a career choice for tertiary business students in Japan-A factor analysis. Accounting Education: an international journal, 18(3), 255-272.

[34] Schoenfeld, J., Segal, G., \& Borgia, D. (2017). Social cognitive career theory and the goal of becoming a certified public accountant. Accounting Education, 26(2), 109-126.

[35] Sugahara, S., Boland, G., \& Cilloni, A. (2008). Factors influencing students' choice of an accounting major in Australia. Accounting Education: an international journal, 17(S1), S37-S54.

[36] Tan, L. M., \& Laswad, F. (2006). Students' beliefs, attitudes and intentions to major in accounting. Accounting Education: an international journal, 15(2), 167-187.

[37] Trump, G. W., \& Hendrickson, H. S. (1970). Education \& professional training. The Journal of Accountancy.

[38] Yusoff, Y., Omar, Z. A., Awang, Y., Yusoff, R., \& Jusoff, K. (2011). Does knowledge on professional accounting influence career choice?. World Applied Sciences Journal, $12,57-60$

[39] Whitehouse, T. (2015). Accounting and Audit Suffering a Talent Shortage. Compliance Week, 12(132), 30-69.

[40] Weer, C. H., Greenhaus, J. H., Colakoglu, S. N., \& Foley, S. (2006). The role of maternal employment, role-altering strategies, and gender in college students' expectations of work-family conflict. Sex Roles, 55(7-8), 535-554. 